\title{
MONITORING JUMLAH BERAS PADA RICE BOX DENGAN SENSOR BERAT DAN SENSOR KELEMBABAN BERBASIS MIKROKONTROLER
}

\author{
Anjaya Riduansyah ${ }^{1}$, Anisya Sonita ${ }^{2}$ \\ ${ }^{1,2}$ Universitas Muhammadiyah Bengkulu \\ Jl. Letjen S. Parman No. 65, 75313 Indonesia \\ 1'Anjayanovi@gmail.com,2Anisyasonita@gmail.com
}

\begin{abstract}
Rice is a main staple food in Indonesia. Delivery of information regarding stockpile especially primary needs as daily provision turns to a problem that's feasible to be automated. Monitoring towards stockpile such as rice can be done automatically. Using microcontroller, load cell sensor, temperature and humidity sensor and also RTC, communicating via GSM Shield, a protoype device for monitoring stockpile could be made. Load Cell sensor taking the role as a weight detector, DHT 11 as a temperature and humidity sensor, RTC serves as date and time provider inside the container, and also GSM Shield as the bridge between system and user via cellular phone. monitoring device will dispatch an information about the stock quantity and act as a reminder as the stockpile dwindle. The acquired information is in the form of text message consists of how much is the stock in weight unit, temperature, humidity and also date and time (at the time of stockpile checking being done).
\end{abstract}

\section{Keywords : Load cell, DHT 11, Microcontroller, GSM Shield}

\begin{abstract}
Abstrak
Beras adalah makanan pokok utama di Indonesia. Penyediaan informasi stok kebutuhan khususnya kebutuhan pokok sebagai persediaan harian menjadi permasalahan yang layak untuk diotomasikan. Monitoring terhadap ketersediaan stok seperti beras dapat dilakukan secara otomatis. Dengan menggunakan mikrokontroler, sensor berat, sensor suhu dan kelembaban, serta RTC dapat dibuat sebuah alat yang dapat memonitoring stok persedian beras dengan bantuan komunikasi dari GSM shield. Dengan sensor Load Cell sebagai pendeteksi berat, DHT 11 sebagai sensor suhu serta kelembaban, RTC yang berfungsi pembaca tanggal serta waktu dalam wadah penyimpanan serta GSM shield yang menjadi penghubung antara sistem dan user melalui perangkat telepon selular. monitoring dapat memberi informasi stok beras dan reminder menipisnya persediaan. Hasil yang diperoleh berupa pesan teks berisi informasi berat, suhu, kelembaban, serta waktu dan tanggal pengecekan beras.
\end{abstract}

Kata kunci : Load cell, DHT 11, Mikrokontroler. GSM Shield

\section{Pendahuluan}

Perkembangan teknologi saat ini sudah semakin canggih. Salah satunya adalah Home Automation atau biasa disebut Smart Home. Home Automation adalah ekstensi perumahan otomasi bangunan. Home Automation memberi kemudahan, kenyamanan, efisiensi energi, otomasi pengontrolan alat dan keamanan. Banyak kegiatan yang dapat diotomasikan di dalam sebuah bangunan ini, salah satunya adalah pengawasan dan pengontrolan terhadap peralatan harian seperti persediaan kebutuhan pokok, seperti stok beras. Indonesia merupakan Negara kepulauan, dimana asupan makanannya paling utama adalah karbohidrat yang berasal dari beras sehingga tingkat kebutuhannya salah satu tertinggi di Benua Asia [6]. Biasanya beras ditempatkan pada sebuah wadah yang biasa disebut Rice Box yang berguna sebagai media penyimpanan dari faktor penyebab berkurangnya kualitas beras untuk dikonsumsi. Dengan mengetahui ketersediaan dan kondisi stok beras menjadi sebuah kebutuhan yang dapat me

permudah dalam pengontrolan ketersediaan dan kualitas stok beras. Kualitas stok beras dapat diketahui melalui tingkat kelembaban, suhu, dan lama stok telah disimpan dalam sebuah Rice Box.

Berdasarkan kondisi tersebut, dibutuhkan monitoring alat dengan kebutuhan informasi dan pengontrolan terhadap stok beras serta informasinya menggunakan mikrokontroler, sensor berat yaitu sensor Load Cell juga sensor kelembaban dengan DHT 11. Sensor Load Cell mengukur berat beras dan sensor DHT 11 mendeteksi kelembaban yang ada dalam box kemudian diolah menggunakan mikrokontroler yang akan memberi notifikasi informasi dan kondisi stok beras. Sensor berat Load Cell juga digunakan sebagai indikator untuk 
reminder stok beras yang telah minipis. DHT 11 juga mengukur tingkat kelembaban dan suhu terhadap beras dalam wadah. Waktu dan tanggal pemgecekan dibaca oleh mikrokontroler dengan membaca sensor Real Time Clock (RTC) dalam wadah.

Data-data informasi tersebut menunjukkan kapasitas ketersediaan stok beras dan tingkat kelembaban box ataupun reminder stok yang menipis akan ditampilkan melalui Short Message Service (SMS) melalui GSM Shield sebagai media komunikasi data [1]. Tingkat akurasi data akan dianalisis persentasenya untuk mengukur tingkat ketelitiannya.

\section{A. Home Automation}

Home Automation adalah ekstensi perumahan otomatisasi bangunan. Beragam kegiatan yang biasa dilakukan didalam bangunan yang dapat diotomatisasikan seperti pengontrol pencahayaan, HVAC (pemanas, ventilasi, dan pendingin udara), peralatan, dan kunci keamanan akses masuk bangunan. Tujuan dari Home Automation adalah untuk memberikan kemudahan, kenyamanan, efisiensi dan keamanan.

\section{B. Mikrokontroler}

Mikrokontroler merupakan komputer yang berukuran kecil di dalam sirkuit terintegrasi tunggal yang di dalamnya terdapat inti prosesor, memori (kapasitas kecil), dan perlengkapan input output. Dengan bentuk yang jauh lebih kecil dari komputer pribadi dan komputer mainframe, mikrokontroler dibangun menggunakan elemen-elemen secara spesifik berdasarkan masukan yang diterima dan program dijalankan. Seperti komputer umumnya, mikrokontroler merupakan alat yang mengerjakan instruksi-intruksi yang diberikan. Jadi, hal yang terpenting dan utama dari suatu sistem terkomputerisasi adalah program yang ditanamkan dan dibuat oleh seorang programmer. Program menginstruksikan komputer untuk melakukan jalinan yang panjang dari aksi-aksi sederhana untuk melakukan tugas yang labih kompleks yang diinginkan oleh seorang programmer [5].

\section{Arduino Uno}

Arduino Uno adalah board mikrokontroler berbasis ATmega328. Arduino Uno ini memiliki14 pin input dari output digital dimana 6 pin input tersebut dapat digunakan sebagai output PWMdan 6 pin input analog, $16 \mathrm{MHz}$ osilator kristal, koneksi USB, jack power, ICSP header, dan tombol reset. Untuk menggunakan Arduino cukup menghubungkan kabel USB dari komputer ke Arduinonya, selain itu bisa juga dengan menggunakan adaptor dan baterai [4].

\section{GSM Shield}

Arduino GSM Shield memungkinkan board Arduino untuk terhubung ke internet, membuat / menerima panggilan suara dan mengirim / menerima pesan SMS. Arduino GSM Shield menggunakan modem radio M10 dari Quectel
( datasheet). Hal ini dimungkinkan untuk berkomunikasi dengan board Arduino dengan menggunakan AT Command [1].

\section{E. Sensor Load Cell}

Load Sensor adalah sensor beban atau sensor pengukur berat. Load Cell merupakan sensor gaya yang banyak digunakkan dalam industri yang memerlukan peralatan untuk mengukur massa [4]. Transduksi massa dapat bervariasi bergantung pada perubahan parameter fisis.

Load Cell adalah alat elektromekanik yang biasa disebut Transducer, yaitu gaya yang bekerja berdasarkan prinsip deformasi sebuah material akibat adanya tegangan mekanis yang bekerja, kemudian merubah gaya mekanik menjadi sinyal listrik. Untuk menentukan tegangan mekanis didasarkan pada hasil penemuan Robert Hooke, bahwa hubungan antara tegangan mekanis dan deformasi yang diakibatkan disebut regangan. Regangan ini terjadi pada lapisan kulit dari material sehingga menungkinkan untuk diukur menggaunakan sensor regangan atau Strain Gauge [3]. Cara kerja sensor Load Cell salah satunya adalah Piezoresistif. Piezoresistif yang popular adalah strain gauge yang memanfaatkan perubahan resistansi strain gauge setiap mendapat deformasi dari posisi setimbang sebagai akibat pembebanan massa tertentu. Strain ( $\varepsilon$ ) adalah sejumlah deformasi pada material sebagai pengaruh dari aplikasi gaya. Lebih khusus lagi, strain didefinisikan sebagai perbandingan perubahan panjang terhadap panjang mula-mula.

\section{F. Sensor DHT 11}

DHT 11 adalah sensor untuk mengukur temperatur dan kelembaban udara yang memiliki jangkauan pengukuran suhu antara $0-50^{\circ} \mathrm{C}$ dan kelembaban udara $20-95 \%$. Sensor ini mempunyai kecepatan baca seperempat detik dan data yang di baca adalah data 2 detik yang lalu. DHT 11 adalah sensor digital yang outputnya menghasilkan baris data 40 bits, yang terdiri dari input 16 bit data temperatur, 16 bit data kelembaban, dan 8 bit data pariti [7].DHT 11 adalah sensor kompleks dengan output kalibrasi sinyal digital yang memastikan keandalan penginderaan kelembaban dan suhu serta stabilitas jangka panjang dengan menggunakan teknik akuisisi sinyal digital yang ekslusif [2].

\section{Metode Penelitian}

\section{A. Perancangan Sistem}

Pada penelitian ini akan dibangun sebuah alat Pemantauan Rice Box dengan menggunakan SMS. Rancangan sistem monitoring memanfaatkan sensor load cell dan DHT 11 seperti gambar berikut, beras di letakkan di dalam box pada wadah besi yang telah didesain sebagai penampung beras. Posisi sensor load cell pada bagian bawah wadah penampung dan DHT 11 ditempatkan pada bagian atas Rice Box. Kabel yang menghubungkan sensor load cell dan DHT 11 tersambung ke kotak hitam yang berisi 
mikrokontroler dan GSM shield. Data berat beras dan suhu serta kelembaban yang didapat pada Rice Box akan dikirim ke mikrokontroler dan diteruskan ke user dengan menggunakan komunikasi dari GSM shield berupa pesan teks. Data berat yang didapat akan dibandingkan dengan berat asli yang telah diukur pada timbangan digital sebelumnya.

\section{B. Perancangan Perangkat Keras}

Dalam penelitian ini akan dibangun sebuah alat dengan perancangan yang membutuhkan komponen perangkat keras agar dapat mengetahui fungsi dan hasilnya. Pada sistem ini, perangkatperangkat akan saling berkoordinasi dan berkomunikasi dalam mengirimkan dan menerima data. Perancangan perangkat keras seperti berikut :

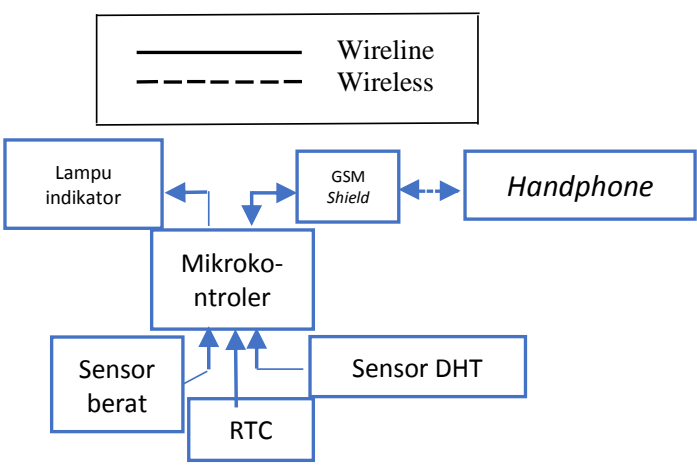

Gambar 2.2 Diagram monitoring Sistem

\section{Perhitungan Persentase Error Untuk \\ Pengukuran}

Dalam suatu pengukuran sering kali dipertanyakan akurasi dari pengukuran tersebut dan alat ukur tidaklah tepat. Akurasi bergantung pada perangkat yang digunakan untuk melakukan pengukuran, tetapi akurasi secara umum dapat dikatakan setengah unit dari tiap sisi dari hasil pengukuran. Misal pengukuran dilakukan dengan ukuran $1 \mathrm{~cm}$, maka nilai antara $5,5 \mathrm{~cm}$ dan $6,5 \mathrm{~cm}$ dianggap sebagai $6 \mathrm{~cm}$.

Untuk mendapatkan persentase error maka dibutuhkan absolute error dimana absolute error adalah selisih nilai sebenarnya dengan nilai hasil pengukuran yang dilakukan. Untuk mendapatkan persentase error maka bagi absolute error dengan nilai sebenarnya dan dikalikan $100 \%$. Berikut rumus persentase error [8]

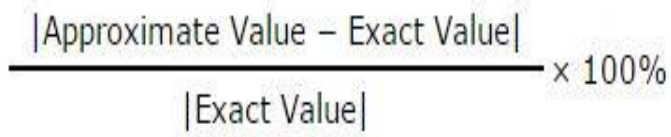

Gambar 2.1 Rumus persentase error

\section{Perangcangan Perangkat Lunak}

Pada bagian perangkat lunak akan dilakukan dengan tahap pengkodean pengecekan pada sensor dan pengiriman notifikasi informasi data berat, suhu, kelembaban, waktu serta tanggal pengecekan dan reminder stok beras.

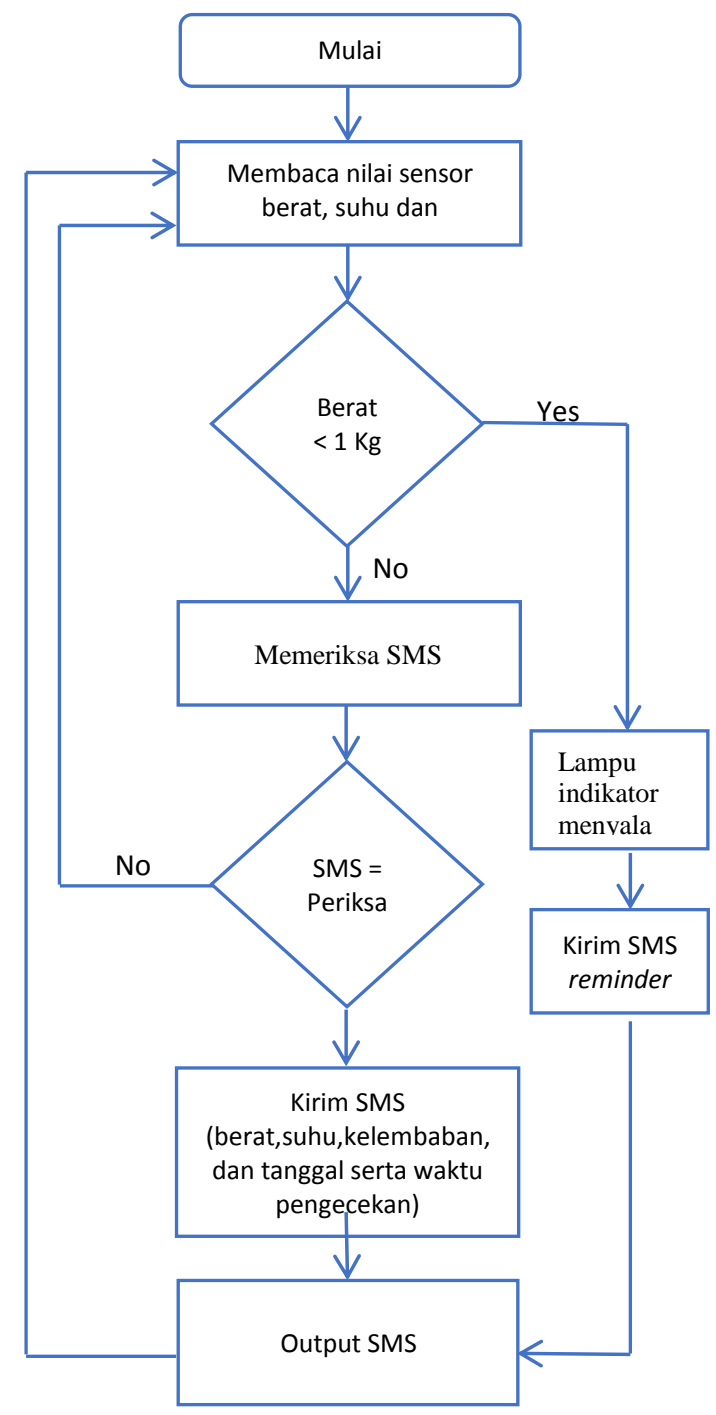

Gambar 2.3 Flowchart membaca sensor berat, suhu dan kelembaban, reminder stok.

Proses dari sistem secara umum adalah sebagai berikut :

1. Mulai, alat telah menyala.

2. Mikrokontroler membaca nilai sensor dalam sistem.

3. Jika nilai sensor berat $<1 \mathrm{Kg}$ maka mikrokontroler melakukan fungsi reminder yaitu SMS warning sebanyak 2 kali dan lampu indikator menyala.

4. Setalah melakukan fungsi reminder, mikrokontroler kembali membaca nilai pada sensor berat, suhu, kelembaba, dan RTC. 
5. Mikrokontroler melakukan pengecekan terhadap SMS dengan kata kunci "Periksa".

6. Jika SMS yang masuk adalah "Periksa" maka mikrokontroler akan mengambil data dari sensor berat, suhu, kelembaban, dan RTC ke nomer yang melakukan pengecekan.

7. Output pada SMS berupa informasi berat, suhu, kelembaban, serta waktu dan tanggal pengecekan dilakukan.

8. Mikrokontroler melakukan pengecekan kembali atau melakukan looping setelah mengirim SMS ataupun melakukan fungsi reminder.

\section{E. Skenario Pengujian}

Pengujian dilakukan untuk mengetahui bagaimana pembacaan terhadap berat di wadah oleh sensor load cell. Dari hasil pengujian dapat diketahui persentase error dalam pembacaan sensor. Hasil pengujian berupa informasi dari Rice Box berupa berat, suhu, kelembaban, dan waktu serta tanggal pengecekan. Untuk mengetahui hasil penelitian dan penerapan pemantauan rice box, maka dibutuhkan suatu pengujian. Adapun pengujian yang dilakukan adalah sebagai berikut :

1. Skenario pertama, pengujian sensor load cell pada skenario pengujian ini dilakukan dengan melakukan pengecekan terhadap Rice Box melalui SMS dengan kata kunci "Periksa". Pengujian dilakukan per kilogram dimulai dengan berat $2 \mathrm{Kg}$. Berat beras asli telah ditimbang dengan alat timbangan digital yang ada. Data pengujian didapat melalui SMS dari alat yang dilakukan pengecekan sebelumnya.

2. Skenario kedua, pengujian reminder berat beras dilakukan dengan mengurangi beras hingga kurang dari $1 \mathrm{Kg}$ dengan gelas takaran yang ada. Pada pengujian ini akan didapatkan SMS reminder stok beras dan lampu indikator menyala sebagai penanda bahwa beras kurang dari $1 \mathrm{Kg}$. Tiap melakukan pengujian, maka akan dicek kembali berkurangnya jumlah stok beras. Pesan reminder dikirim ke nomer 0899963203 dan 08984996086 sebagai nomer yang telah ditetapkan untuk menerima pesan reminder kurang dari $1 \mathrm{Kg}$. Pengujian dilakukan untuk mengetahui reminder berfungsi atau tidak. Pengujian dilakukan dari stok beras $2 \mathrm{Kg}$. Pada pengujian, pengurangan beras dilakukan bertahap hingga reminder SMS dan lampu indikator menyala.

3. Skenario ketiga, pengujian monitoring penggunaan beras dilakukan selama 7 hari. Pengujian dilakukan untuk monitoring penggunaan beras rumah tangga sehari - hari yang beranggotakan $4-5$ orang. Dalam pengujian ini dapat dilihat grafik penggunaan beras rumah tangga. Pengujian dilakukan dengan mengisi beras pada wadah di hari pertama sebanyak $6 \mathrm{Kg}$ selama 5 hari. Pada hari ke 6 dilakukan pengisian kembali sebanyak 1 $\mathrm{Kg}$.

\section{F. Manfaat Penelitian}

1.Menambah wawasan mengenai pengoperasian piranti mikrokontroler dan membangun suatu inovasi alat yang layak digunakan.

2. Membantu masyarakat dalam menakar beras sesuai angka kecukupan gizi (AKG).

3. Mengurangi pemborosan dalam pengolahan beras dengan takaran yang pas.

4. Memberikan informasi jumlah beras di dalam rice box serta mengingatkan pengguna untuk mengisi beras ketika sisa beras hampir habis .

5. Sebagai bahan informasi dan referensi untuk pengembangan bagi penelitian berikutnya.

\section{Hasil \& Pembahasan}

\section{A. Hasil Pengujian Sensor Load Cell}

Pengujian sensor load cell dilakukan dengan melakukan pengecekan terhadap Rice Box melalui SMS dengan kata kunci "Periksa". Pengujian dilakukan per kilogram dimulai dengan berat $1 \mathrm{Kg}$. Berat beras asli telah ditimbang dengan alat timbangan digital yang ada.

Tabel 3.1 Pengujian sensor Load Cell Per Kilogram

\begin{tabular}{|c|c|c|c|c|}
\hline $\begin{array}{c}\text { SMS } \\
\text { ke }-\end{array}$ & $\begin{array}{c}\text { Berat } \\
\text { di uji } \\
(\mathrm{Kg})\end{array}$ & $\begin{array}{c}\text { Berat } \\
\text { terbaca } \\
(\mathrm{kg})\end{array}$ & $\begin{array}{c}\text { Selisih } \\
\text { berat } \\
(\mathrm{kg})\end{array}$ & $\begin{array}{c}\text { Error } \\
(\%)\end{array}$ \\
\hline 1 & 8 & 8,13 & 0,13 & 1,63 \\
\hline 2 & 8 & 8,02 & 0,02 & 0,25 \\
\hline 3 & 8 & 8,22 & 0,22 & 2,75 \\
\hline 4 & 8 & 8,19 & 0,19 & 2,37 \\
\hline 5 & 8 & 8,28 & 0,28 & 3,50 \\
\hline \multicolumn{2}{|c|}{ Rata - rata } & 8,17 & 0,17 & 2,10 \\
\hline
\end{tabular}

Pengujian yang dilakukan pada salah satu berat yaitu $8 \mathrm{Kg}$. Hasil yang diperoleh terdapat noise atau perbedaan nilai tiap. Pada pengujian yang dilakukan diperoleh rata - rata berat $8 \mathrm{Kg}$ terbaca $8,17 \mathrm{Kg}$, selisih atau noise yaitu $0,17 \mathrm{Kg}$ serta nilai error 2,10 $\%$. Hasil data yang diperoleh per kilogram akan diambil nilai rata-ratanya. Tiap pengecekan per kilogram dilakukan SMS sebanyak 5 kali. Data dari pesan teks pada perangkat handphone yang diterima pada pengecekan 1 - $10 \mathrm{Kg}$ adalah sebagai berikut :

Tabel 3.2 Hasil pengujian sensor Load Cell

\begin{tabular}{|c|c|c|c|}
\hline $\begin{array}{c}\text { Berat } \\
\text { beban } \\
(\mathrm{kg})\end{array}$ & $\begin{array}{c}\text { Rata - rata } \\
\text { berat terbaca } \\
(\mathrm{kg})\end{array}$ & $\begin{array}{c}\text { Rata - rata } \\
\text { selisih berat } \\
(\mathrm{kg})\end{array}$ & $\begin{array}{c}\text { Rata - rata } \\
\text { persentase } \\
\text { error }(\%)\end{array}$ \\
\hline 1 & 1,01 & 0,01 & 1,00 \\
\hline
\end{tabular}




\begin{tabular}{|c|c|c|c|}
\hline 2 & 2,04 & 0,04 & 2,00 \\
\hline 3 & 3,09 & 0,09 & 3,00 \\
\hline 4 & 4,11 & 0,11 & 2,75 \\
\hline 5 & 5,13 & 0,13 & 2,60 \\
\hline 6 & 6,13 & 0,13 & 2,17 \\
\hline 7 & 7,15 & 0,15 & 2,14 \\
\hline 8 & 8.17 & 0,17 & 2,13 \\
\hline 9 & 9.22 & 0,22 & 2,44 \\
\hline 10 & $10, .38$ & 0,38 & 3,80 \\
\hline \multicolumn{2}{|c|}{ Rata-rata } & 0,14 & 2,40 \\
\hline
\end{tabular}

Berdasarkan tabel load cell yang digunakan dapat dilihat nilai error tertinggi adalah 3,80\% pada berat $10 \mathrm{Kg}$ dan rata-rata nilai error 2,40\%. Error pada sensor dipengaruhi banyak faktor salah satunya tekanan (Force) menjadi sinyal listrik. Salah satu cara load cell mengubah nilai Force adalah Strain Gauge. Pada pengujian load cell ini, penampung atau wadah tersebut sengaja diletakkan di dalam ricebox agar tepat berada di tengah dimana alas atau dudukan penampung beban yang berada di atas load cell bergeser dikarenakan beban yang ditampungya. Hal tersebut mempengaruhi pembacaan terhadap berat beban yang ada sehingga adanya noise atau perbedaan data berat pada pengujian kilogram yang sama.

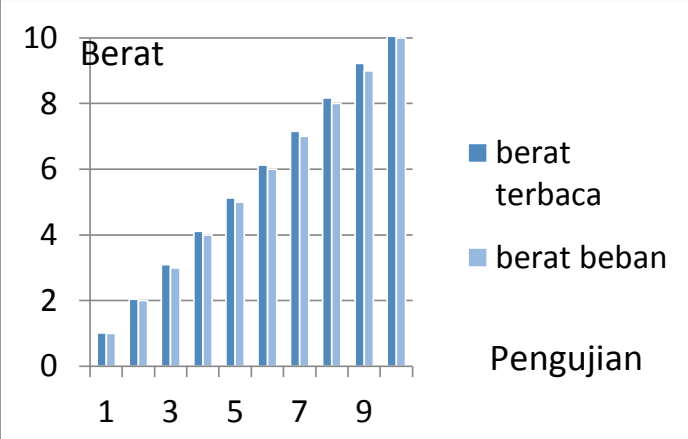

Gambar 3.1 Perbandingan Berat Asli Dan Sensor Load Cell

Dari perbandingan berat asli dan berat yang terbaca, dapat dilihat bahwa semakin besar berat beban dalam pengujian maka semakin besar juga selisih berat yang terbaca pada sensor. Hal ini menyebabkan nilai error dan noise semakin besar atau berbanding lurus terhadap nilai yang ada.

\subsection{Hasil Pengujian Reminder}

Pengujian ini dilakukan untuk mengetahui apakah reminder apabila berat beras dalam wadah kurang dari atau sama dengan $1 \mathrm{~kg}$ berfungsi dengan mengirimkan pesan teks atau SMS reminder warning ke nomer yang ada dan lampu indikator menyala. SMS dikirimkan sebanyak 2 kali untuk menekan biaya SMS.
Tabel 3.3 Pengujian Reminder

\begin{tabular}{|c|c|c|c|c|}
\hline $\begin{array}{c}\text { Pengujian } \\
\text { ke - }\end{array}$ & $\begin{array}{c}\text { Beras } \\
\text { terbac0a } \\
(\mathrm{Kg})\end{array}$ & $\begin{array}{c}\text { Lampu } \\
\text { indikator }\end{array}$ & $\begin{array}{c}\text { SMS } \\
\text { masuk }\end{array}$ & Status \\
\hline 1 & 2,07 & mati & tidak & sesuai \\
\hline 2 & 1,83 & mati & tidak & sesuai \\
\hline 3 & 1,64 & mati & tidak & sesuai \\
\hline 4 & 1,17 & mati & tidak & sesuai \\
\hline 5 & 0,89 & hidup & ya & sesuai \\
\hline 6 & 2,04 & mati & tidak & sesuai \\
\hline 7 & 1,97 & mati & tidak & sesuai \\
\hline 8 & 1,54 & mati & tidak & sesuai \\
\hline 9 & 1,33 & mati & tidak & sesuai \\
\hline 10 & 0,77 & hidup & ya & sesuai \\
\hline 11 & 1,88 & mati & tidak & sesuai \\
\hline 12 & 1,65 & mati & tidak & sesuai \\
\hline 13 & 0,92 & hidup & ya & sesuai \\
\hline
\end{tabular}

Pada tabel di atas, pengujian dilakukan sebanyak 3 kali dimana terdapat 13 kali pengujian. Pada pengujian 1 sampai dengan 4, lampu indikator tidak menyala dan tidak ada SMS reminder yang masuk sedangkan pada pengujian ke 5 berat beras kurang dari $1 \mathrm{Kg}$ yaitu $0,89 \mathrm{Kg}$ dan lampu menyala serta SMS reminder diterima oleh perangkat Handphone. Pada pengujian ke 6 beras ditambahkan $1 \mathrm{Kg}$ kembali setelah adanya reminder dan dilakukan kembali hingga pengujian ke 10. Pada

pengujian ke 10 beras berada pada nilai $0,77 \mathrm{Kg}$ dan lampu menyala serta terdapat SMS masuk ke handphone. Kemudian dilakukan pengisian kembali $1 \mathrm{Kg}$ pada pengujian ke 11 kemudian dilakukan pengujian kembali. Pada pengujian ke 13 beras berada pada nilai $0,92 \mathrm{Kg}$ lampu indikator hidup dan SMS reminder di terima perangkat handphone. Dari tabel tersebut, fungsi reminder sesuai nilai berat yang kurang dari $1 \mathrm{Kg}$ dan menghasilkan akurasi $100 \%$.

\subsection{Hasil Monitoring Stok Beras}

Pada pengujian ini, dilakukan pengecekan terhadap stok selama 7 hari, yang mana didapat grafik penggunaan beras yang telah diambil dari Rice Box. Pada pengujian ini beras yang ada di dalam wadah yaitu $6 \mathrm{Kg}$ :

Tabel 3.4 Monitoring Stok Beras

\begin{tabular}{|c|c|c|c|c|}
\hline Hari & $\begin{array}{c}\text { SMS } \\
\text { ke- }\end{array}$ & $\begin{array}{c}\text { Berat } \\
(\mathrm{kg})\end{array}$ & Suhu $\left({ }^{\circ} \mathrm{C}\right)$ & $\begin{array}{c}\text { Kelembaban } \\
(\%)\end{array}$ \\
\hline \multirow{3}{*}{1} & 1 & 6,06 & 25 & 71 \\
\cline { 2 - 5 } & 2 & 5,86 & 24 & 72 \\
\cline { 2 - 5 } & 3 & 5,23 & 24 & 74 \\
\hline 2 & 4 & 5,35 & 24 & 75 \\
\hline
\end{tabular}




\begin{tabular}{|c|c|c|c|c|}
\multirow{2}{*}{} & 5 & 5,16 & 24 & 77 \\
\cline { 2 - 5 } 3 & 6 & 4,66 & 24 & 77 \\
\hline \multirow{4}{*}{3} & 7 & 4,7 & 25 & 74 \\
\cline { 2 - 5 } & 8 & 4,31 & 24 & 74 \\
\cline { 2 - 5 } & 9 & 4,2 & 24 & 79 \\
\hline \multirow{4}{*}{5} & 10 & 4,23 & 24 & 80 \\
\cline { 2 - 5 } & 11 & 4,19 & 24 & 77 \\
\cline { 2 - 5 } & 12 & 4,03 & 24 & 81 \\
\hline \multirow{4}{*}{6} & 13 & 4,09 & 25 & 78 \\
\cline { 2 - 5 } & 14 & 3,82 & 24 & 78 \\
\cline { 2 - 5 } & 15 & 3,23 & 24 & 80 \\
\hline \multirow{3}{*}{7} & 16 & 4,40 & 24 & 80 \\
\cline { 2 - 5 } & 17 & 4,3 & 24 & 71 \\
\hline & 18 & 3,96 & 25 & 73 \\
\hline & 19 & 4,02 & 24 & 73 \\
\cline { 2 - 5 } & 20 & 3,31 & 24 & 74 \\
\hline \multirow{2}{*}{} & 21 & 2,86 & 24 & 74 \\
\hline
\end{tabular}

Pada tabel di atas, pengujian dilakukan dengan monitoring beras $6 \mathrm{Kg}$ pada hari pertama sampai hari ke 5 dan hari ke 6 dilakukan pengisian kembali beras sebanyak $1 \mathrm{Kg}$. Pada pengujian pertama dan ketiga dihari sebelumnya, beras tidak mengalami pengurangan, namun didapat nilai yang berbeda seperti yang dapat dilihat pada tabel diatas pada SMS ke 3 - 4, 6 - 7, 9-10, 12 - 13, 15 - 16, dan SMS ke 18 -19. Hal tersebut merupakan noise yang ada pada berat yang terbaca dalam nilai kilogram yang sama. Noise tersebut telah dilakukan pada pengujian load cell sebelumnya.

\section{Pengujian Sistem}

Pengujian sistem ini berkaitan dengan pengujian Rice Box yang dibuat. Pengujian ini dilakukan untuk mengetahui tingkat performansi kinerja sistem dari monitoring Rice Box tersebut dan tingkat keakuratan pengeluaran beras yang akan diinginkan oleh user.

Pengujian yang dilakukan, merupakan pengujian terhadap berat beras dengan memanfaatkan sensor load cell yang berperan membaca berat beras yg ada pada wadah di dalam ricebox melalui pesan teks pada perangkat handphone. Isi dari pesan teks tersebut atau SMS adalah berat beras, suhu, kelembaban dari sensor DHT 11 serta waktu dan tenggal pengecekan Rice Box. Skenario dilakukan untuk menguji fungsionalitas sistem yang dibuat apakah berhasil memberikan hasil dari berat beras yang ada pada wadah dengan sensor load cell, DHT 11, dan RTC melalui SMS yang diterima oleh ponsel. Untuk pengujian dilakukan dengan melihat per kilogram dari berat beras yang akan diuji yaitu 1 $-10 \mathrm{~kg}$.

\section{Kesimpulan}

Berdasarkan hasil pengujian dan analisis terhadap akurasi Aplikasi Pemantauan Rice Box menggunakan SMS, maka dapat ditarik kesimpulan sebagai berikut :
1. Pemantauan Rice Box Dengan Sensor Berat dan Sensor Kelembaban Berbasis Mikrokontroler menggunakan SMS dapat dibangun dan berfungsi dengan benar.

2. Rata-rata error sensor load cell $2,40 \%$ dengan maksimum nilai error pada pengujian yang dilakukan penulis adalah sebesar 3,80\% dan terkecil adalah $1 \%$. Nilai error dan noise dikarenakan bentuk penyangga wadah yang berpengaruh terhadap sensor load cell membaca informasi berat beras yang ada, namun bisa lebih baik bila penyangga wadah lebih kokoh.

3. Fungsi reminder menghasilkan akurasi $100 \%$ dimana kondisi lampu dan SMS berfungsi saat beras kurang dari $1 \mathrm{Kg}$.

4. Monitoring penggunaan beras harian pada konsusmsi rumah tangga dapat dilakukan dengan melihat grafik penggunaan beras pada pengujian yang dilakukan.

\section{Daftar Pustaka}

[1] Arduino, 2015, Arduino GSM Shield, [Online] Tersedia di http://arduino.cc/en/Guide/ArduinoGSMShield

[2] D-Robotics, 2010, DHT 11 Humidity \& Temperature Sensor, [pdf], (www.micropik.com/PDF/dht11.pdf, diakses tanggal 17 april 2015)

[3] Kitomaindonesia, 2015, Load Cell dan Timbangan, [Online] Tersedia di http://www.kitomaindonesia.com/article /23/load-cell-dan-timbangan

[4] Load Cell Teori, 2011, Load Cell Teori/ Load Cell Handbook,

[Online] Tersedia di https://loadcellteori.wordpress.com/2011/ 04/05/load-cell-teori-manual-load-cell/

[5] M. Syahwil, "Mikrokontroler, in Panduan Mudah Simulasi \& Praktek Mikrokontroler Arduino”, Yogyakarta, Andi, 2013, pp. 53-55.

[6] Neraca, 2013, Konsumsi Beras Nasional tertinggi Se-Asia, [Online] Tersedia di http://www.neraca.co.id/article/26605/ Konsumsi-Beras-Nasional-Tertinggi-SeAsia

[7] Rustamaji, 2014, Mengukur Temperature dan Kelembaban Udara, [Online]

Tersedia di http://www.rustamaji.net/id/arduino/ mengukur-temperature-dan-kelembaban-udara

[8] mathisfun.com. (2014) mathisfun.com. [Online]. https://www.mathsisfun.com/measure/error$\underline{\text { measurement.html }}$ 